DOI: 10.20472/IAC.2018.935.006

\title{
CHOOSRI BANDITVILAI
}

Faculty of Liberal Arts and Science, Thailand

\section{FACTORS THAT AFFECT THAI UNIVERSITY STUDENTS' READING COMPETENCE}

\begin{abstract}
:
This research study was conducted to survey factors that affect the reading competence of Thai university students. The participants were the second year undergraduate English major students who registered to study "English Reading" at Kasetsart University. The research tools used in this study were a survey questionnaire and a semi-structured interview. The statistical method for data analyses were percentage, mean value (x) and standard deviation (SD). A summary was made of key points from the semi-structured interview. Based on both statistical data of the questionnaire and an interview, it was found that the major factors were firstly an inadequate knowledge of vocabulary and sentence structure, followed by a lack of background knowledge, an inability to grasp the main ideas and lastly the inability to understand the writer's purpose and style.
\end{abstract}

\section{Keywords:}

English reading, reading competence, reading strategies, English as a foreign language (EFL), second-language (L2)

JEL Classification: 120,129 


\section{Introduction}

Reading is a necessary skill in education and every occupation. Readers can gain knowledge and keep up- to-datewith the news around the world through reading. In reading, the readers are not only able to understand the words but also interpret and evaluate what they are readng by using personal experience. Reading is an interactive process between the reader's background knowledge and the text itself. Richek (1996) states that students' inability to read will affect their abilities to get a job in the future. In 2015, Thailand as a member of Association of Southeast Asian Nations (ASEAN) had the leading role among the ASEAN countries. According to The ASEAN Charter (2013), "Article 34 states that the working language of ASEAN shall be English", so English has become an important language in ASEAN countries. English has been taught as a foreign language and it is a compulsory language subject in Thailand. Most Thai students start learning English from kindergarten onwards. However, few Thais are fluent in English compared with other ASEAN countries. In a traditional Thai reading class, most Thai teachers start teaching vocabulary and grammatical structure. Students are asked to read and translate sentence by sentence. However, students still do not understand a text that leads to being unsuccessful in reading comprehension tests in the classroom. Mc Carthy (1990) stated, "No matter how well the student learns grammar, no matter how successfully the sounds of $L 2$ are mastered, without words to express a wide range of meaning, communication in an L2 just cannot happen in any meaningful way."

\section{$2 \quad$ Reading strategies}

Gardner (1987, cited in Kletzien, 1991:69) states that "A reading strategy" is an action that is employed in order to construct meaning." Paris et al (1991) classified reading strategies into three categories based on when they were used: Pre-reading, while-reading and postreading.

The purposes of pre-reading is to activate students' background knowledge from personal experience.

Pre-reading is designed to...

1) Provide a general idea of the content of a text prior to detailed reading.

2) Assist the reader in deciding whether or not to read the text in detail.

3) Activate the mind of the reader to become involved with the text.

4) Enable easier and faster reading.

The main activities in pre-reading are making predictions about the content of a text. Teacher asks the students to read the title, look at the picture and try to predict what the story is about. Students use their experiences and knowledge to make predictions about 
the content of the story. Carrell (1984: 334) claims that: "Activating existing background knowledge as well as building new background knowledge should be done through prereading activities to help the reader to read better."

The purpose of while reading is to build understanding of the text and become engaged in the reading process.

While-reading is designed to 1) Build the students' understanding of the text and become engaged in the reading process. 2) Help to locate the main idea. 3) Help in understanding the writer's purposes, style and skills. 4) Improving understanding of the text structure and clarify text context.

The purpose of post reading is to have a deeper understanding of the texts. Now readers have to summarize major ideas and evaluate their readings (Blachowicz \& Ogle, 2001).

Post reading is design to 1) Consolidate or reflect on what has been read. 2) Relate the text to the learners' knowledge, interests or views.

\section{Participants}

The participants in this study were253second-year undergraduate English major students from the Faculty of Liberal Arts and Science. They were all Thai. Their ages ranged from 18 to 20 . All students were informed that their identities would be kept anonymous.

\section{Instruments}

The research instruments used in this study were a questionnaire and a semi-structured interview. The questionnaire was given at the end of the course to all students who studied "English Reading" in the first semester of the academic year 2017. The questionnaire was divided into 2 parts. The first part was general questions about the students' English reading strategies. The second part was composed of questions that determined the perception of students on factors affecting students' reading competence based on a fivepoint Likert scales. Semi-structured interview was used to obtain additional information and clarification of the questionnaire data. 


\section{Examples of research questions and instruments}

\begin{tabular}{|l|c|}
\hline 1. What are the students' reading strategies and problems? & $\frac{\text { Qnstruments }}{\text { Questionnaire }}$ \\
\hline 2. What are the factors affecting students' reading skills? & $\begin{array}{c}\text { Questionnaire \& } \\
\text { Semi-structured } \\
\text { interview }\end{array}$ \\
\hline
\end{tabular}

\section{Data Analysis}

The data obtained from the questionnaire were analyzed using means (M), and standard deviation (SD). Percentages were used in the analysis of students' reading strategies.

\section{$6 \quad$ Findings}

The results of this study will be presented in two parts: reading strategies and factors affecting students' reading competence.

Figure 1: Number and percentage of participants' reading strategies

\begin{tabular}{|l|c|c|}
\hline \multicolumn{1}{|c|}{ Reading strategies } & Number & Percentage \\
\hline Read the title to predict what the story will be about & 210 & 83.00 \\
Make use of pictures, captions, illustrations to understand & 198 & 78.26 \\
text meaning & 180 & 71.14 \\
Use background knowledge to assist in the learning of new & 220 & 86.95 \\
information & 180 & 71.14 \\
Read the first paragraph & 180 & 71.14 \\
Use skimming to find a general idea & 200 & 79.05 \\
Use scanning to find specific information & 242 & 95.65 \\
Pay attention to key words in sentences & 190 & 75.09 \\
Read all of the information to get the details & 232 & 91.69 \\
Guess the meanings of unknown words by using the context & 220 & 86.95 \\
Use dictionary to find meaning of unknown word & 160 & 63.24 \\
Read the last paragraph & & \\
Summarize the major ideas in a text
\end{tabular}


Figure 1 showed that 232 out of 253 students who registered to study "English Reading" used a dictionary to find the meaning of unknown words. Only 190 students guessed the meanings of unknown words from the context. In addition, 242 students read all of the information to get the details. 220 students read the first paragraph and the last paragraph. 210 students read the title to predict what the story would be about. 200 students paid attention to key words. 198 students made use of pictures and captions. 180 students used skimming, scanning and background knowledge to assist their reading and 160 students summarized the major ideas in a text.

Figure 2: Factors affecting students' reading competence

\begin{tabular}{|l|c|c|}
\hline \multicolumn{1}{|c|}{ Problems } & Mean & $\begin{array}{c}\text { Standard } \\
\text { Deviation }\end{array}$ \\
\hline $\begin{array}{l}\text { Don't understand the } \\
\text { passage and can't catch } \\
\text { the main ideas of the } \\
\text { passage }\end{array}$ & 4.54 & 0.65 \\
\hline $\begin{array}{l}\text { Don't have background } \\
\text { knowledge about the } \\
\text { topic }\end{array}$ & 4.58 & 0.64 \\
\hline $\begin{array}{l}\text { Don't know the } \\
\text { vocabulary and the } \\
\text { sentence structure }\end{array}$ & 4.76 & 0.52 \\
\hline $\begin{array}{l}\text { Don't understand the } \\
\text { structure of the passage }\end{array}$ & 4.60 & 0.57 \\
\hline $\begin{array}{l}\text { Don't understand the } \\
\text { writer' purpose and } \\
\text { style }\end{array}$ & 4.54 & 0.65 \\
\hline
\end{tabular}

As can be seen from figure 2,the main difficulty as perceived by the students was inadequate knowledge of vocabulary and sentence structure. The second problem was lack of background knowledge and inability to grasp the main ideas. The third one was inability to understand the writer's purpose and style.

\section{The data from the results of semi-structured interviews}

The results of the semi-structured interviews revealed some of the factors that influence students' English reading competence.

The following are some quotes from the students' stated reasons: 
"I can't understand the story because I can't catch the main idea."

"The story about "The Origins of the Thais" is too difficult for me to understand because the vocabulary is difficult and I don't have enough knowledge about this topic."

"I don't know the meaning and the expressions about the passage."

"I think the passage "Fire in the Sky" is the most difficult passage because there is too much difficult vocabulary and sentence structure is too difficult for me to understand."

“I don't know too much vocabulary so I can't guess the meaning of unknown words from the context."

\section{Conclusion and discussion}

The results of this study can be concluded that factors affecting students' reading competence were inadequate vocabulary and sentence structure. This was followed by a lack of background knowledge in a topic and inability to catch the main ideas. Vocabulary knowledge is very important for helping students to understand the complex materials and contexual clues that help the students guess word meaning. In addition, background knowledge in a topic is also help the students make predictions about the content of a text. Students can use background knowledge to relate new information from a text into their previous information. Therefore, activating students' background knowledge before reading about a specific topic will aid their reading and the familiarity with the content has an important effect on levels of comprehension (Nunan, 1985).

\section{Acknowledgements}

The author would like to thank English (Special Program) at the Faculty of Liberal Arts and Science, Kasetsart University, Kamphaeng Saen campus for funding and supporting this research project.

\section{References}

Bernhardt, E. B. and James, C. J. (1987). The Teaching and Testing of Comprehension in Foreign Learning. Proficiency, and Professionalism in Foreign Language Education. 1987, s. 65-81.

Blachowicz, C. \& Ogle, D. (2001). Reading Comprehension: Strategies for Independent Learners. New York: Guildford Press.

Bowornwattanaset, C. (2014). Casual Factors Influencing English Reading Comprehension Ability of Lower Secondary School Students. RMUTSB Acad. 2014, Vol. 2, No. 2, s. 183-192. 
Carrell, P. L. (1983). Background Knowledge in Second Language Comprehension. Eisterhold. TESOL Quarterly. 1983, Vol. 17, No. 4.

Chawwang, N. (2008). An Investigation of English Reading Problems of Thai 12th Grade Students in Nakhonratchasima Educational Regions 1, 2, 3, and 7. Thesis, M. A. (English). Bangkok: Graduate School, Srinakharinwirot University.

Gardner, R. (1987). Metacognition and Reading Comprehension. Norwood, NJ: Ablex Publishing.

Kletzien, S. (1991). Strategy Use by Good and Poor Comprehension Reading Expository Texts of Different Levels. Reading Research Quaterly. 1991, Vol. 26, No. 1, s. 67-86.

Nunan, D. (1985). Content Familiarity and the Perception of Textual Relationship in Second Language Reading. RELC Journal. 1985, Vol. 16, No. 1, s. 43-51.

Ozek, Y. \& Civelek, M. (2006). A Study on the Use of Cognitive Reading Strategies by ELT Students. The Asian EFL January 14.

Paris, S. G., Wasik, B. A. \& Turner, J. C. (1991). The Development of Strategic Reading. In R. Barr, M. L. Kamil, P. B. Mosenthal \& P.D. Pearson (eds). Handbook of Reading Research. 1991, Vol. 2, s. 609640. New York: Longman.

Richek, M. \& Caldwell. (1996). Reading Problems Assessment and Teaching Strategies. Boston: Allyn \& Bacon.

Rumelhart, D. (1980). Schemata: The Blocks of Cognition. In R.J. Spiro, B.C. Bruce \& W. F. Brewer (Eds). Theoretical Issues in Reading Comprehension. Hillsdale. Nj Erlbaum.

Shen, M. Y. (2013). Toward an Understanding of Technical University EFL Learner's Academic Reading Difficulties, Strategies and Needs. Electric Journal of Foreign Language Teaching. 2013, Vol. 10, No. 1, s. 70-79. Retrieved from http://e-fit.nus.edu.sg/v10n12013/shen.pdf.

Yi, X. \& Zhang, D. (2006). A Psychological Analysis of English Reading Difficulty of Chinese Colleague Learners. Retrieved February 14, 2011 from http://www.aare.edu.au/06pap/yi06855.pdf 